\title{
DIFFERING PERSPECTIVES ON SCHOOL SEGREGATION ISSUES IN AMERICAN CHILDREN'S PICTURE BOOKS
}

\author{
EWA KLĘCZAJ-SIARA \\ Faculty of Philology and Pedagogy, \\ Kazimierz Pulaski University of Technology and Humanities in Radom, \\ ul. Chrobrego 31, 26-600 Radom \\ E-mail address: e.kleczaj@uthrad.pl \\ ORCID: https://orcid.org/0000-0003-3769-2728
}

\begin{abstract}
Aim. School segregation is a common theme of children's books on minority groups living in the United States. Although it is primarily associated with black-white racial divisions, currently it also concerns white-Latino or rich-poor disparities. The aim of this paper is to analyse children's picture books featuring Latino and African American characters who participate in the struggle against school segregation. The authors of the books, being members of racial minorities themselves, offer differing perspectives on the problem. Although they criticise school segregation, they also focus on the white perspective and the reasons why integrating schools has always been hard to achieve.

Methods. The study analyses the visual and verbal narratives of selected picture books using a variety of methods for examining this literary format. Among others, it applies the theory of picture book analysis by Martin Painter, William Moebius, Maria Nikolajeva and Carole Scott.

Results. The article shows that despite the existing scholarship on race-related problems in American schools, children's literature seems to be the medium which tries to explain the problem to youngsters being directly involved in the system of segregation.

Conclusions. The results can be useful to educators who cope with the issue of racial diversity in American schools. They may consider using selected titles of children's literature as teaching aids assisting students from minority groups in the process of self-development and empowerment.

Key words: racial segregation, American schools, picture books, text-image relationships, children's literature
\end{abstract}

\section{INTRODUCTION}

The struggle of minority groups to end racial inequality has been a common 1 theme of African American children's books. Most of the stories feature historical figures organising protests and encouraging other Black Americans

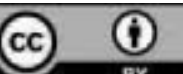


to resist the existing social order. These adult characters participate in actions which are usually beyond the experiences of most children. If young people personally face racial discrimination, it is usually in school rather than on a political rally or protest. Thus, children's books on the topic of school segregation seem to be more appealing and more relevant to young readers than the stories concerning some other political or social issues of their race.

Although school segregation is primarily associated with black-white division, it also concerns other minority groups. In recent years, new patterns of segregation have emerged along racial lines such as Latino-white or Asian-white. Socioeconomic and demographic changes have also created more segregation in contemporary American schools. Due to their appearance, cultural behaviour or language skills, children of immigrants may be refused spots in a white school or treated as inferior by fellow students as well as teachers. As Will Stancil (2018) writes in his article "School segregation is not a myth," racially divided schools are now one of the largest problems of the American education system. He gives numerical evidence that school segregation is a growing phenomenon in the United States, especially for African American students:

(...) the number of segregated schools (defined in this analysis as those schools where less than 40 percent of students are white), has approximately doubled between 1996 and 2016. In that same span, the percentage of children of colour attending such a school rose from 59 to 66 percent. For lack students, the percentage in segregated schools rose even faster, from 59 to 71 percent. (Stancil, 2018)

These demographic changes do not only concern individual schools but more often the entire school districts. The newly opened schools allow students from limited social backgrounds and tend to be segregated. The student population of those schools is usually disproportionately white and middle-class, which indicates that race and income segregation are intertwined. Another issue is the recent fragmentation of large school districts in some parts of the country, which are divided along racial lines, leaving children of colour in poor, underfunded schools rather than offering them new educational opportunities. In addition, the growing number of charter schools, operating independently of the district, lead to further resegregation of American schools.

Modern school segregation is also connected with "tracking," which is a practice of educating students along different paths depending on their on their academic performance. As Sonali Kohli writes, tracking leads to further class inequality and a large achievement gap in American schools, with white and Asian students being on one side, and Black and Latino students on the other (Kohli, 2014). As a result of the tracking system, African American and Latino students are frequently held back as they happen not to receive their teachers' recommendation to take higher level classes. What is also important to note is that tracking is primarily a racial rather than a class issue. Except for many poor Black Americans, there are plenty of middle-class Black students who are sent to lower-level classes (Kohli, 2014). Reduced academic achievement 
of those students is only one of the drawbacks of this system. Another thing is the social issue. As Stancil rightly observes, "Children in integrated schools find it easier to live and work in diverse environments; children in segregated schools are more prone to hold racially prejudiced views later in life" (Stancil, 2018). This leads to the problem of second-class citizenship, which is born in the minds of children attending segregated schools.

The issue of school segregation has been of great interest to American scholars who do a great job by offering advice to practicing educators. Although this kind of research aims to improve the American education system, it does not assist the American minority students in their efforts to understand their place in American schools. Education scholars who touch upon the issue of school segregation, whether in their scholarly publications or in the media, do not address children with their findings. Children's literature seems to be the medium which tries to explain the problem to youngsters being directly involved in the system of segregation. Storytelling, based on the experiential knowledge of people of colour, is empowering to those who are often silenced while trying to talk publicly about their educational problems.

\section{THE VALUE OF EDUCATION}

The topic of school segregation cannot be discussed without mentioning the value of education for members of selected minority groups. The fact that they are less educated than whites and have bigger numbers of school drop-outs does not mean that coloured people do not value education at all. Historically, being denied access to formal education, many of them strove for literacy, which was often synonymous with freedom or better quality of life. In the pre-Civil Rights period many Black Americans pursued their education in order to challenge the existing racial divisions. In her discussion of African American children's books on segregated schools, Michelle Martin explains the difficulties of pursuing education for Black youth: "To obtain access to literacy, then, African Americans must either learn subversively or take part in the revolution that will change the unjust system" (Martin, 2004, p. 140).

In African American communities children's education has always been a communal rather than individual issue. Black Americans have been collectively struggling against educational restrictions or inferior teaching programmes for their children. On many occasions they had to face violence from white students and their parents as well as local school boards. Except the physical effort and suffering involved, there are a lot of success stories of effective educational improvements in segregated as well as integrated schools. The role of the church as a local support institution is unquestionable here as well. Being the religious as well as political centre of Black communities, the church has played a leading role in the process of bettering public education for African Americans. It has organised fund-raising actions as well as stressed the connection between literacy and religious faith. 
Carole Boston Weatherford's picture book Dear Mr. Rosenwald (2006) provides a good example of the how the Black church promotes literacy and supports the local Black community which collects funds to build a new school for their kids. Unlike most of the books on school segregation, this one celebrates the educational opportunities offered to African American children living in the South. The author seems to ignore the fact that the school is racially segregated. Instead she focuses on the benefits and future prospects of the school. Written in the form of several poems accompanied with double spread watercolour illustrations, it tells the story of one Black school's innovation operated with the funds of Julius Rosenwald, a millionaire who invested a large part of his money in southern Black schools. The programme required that the local community collect part of the money on their own before they receive the resources from Rosenwald's foundation. In Weatherford's book the idea of building a new school is announced in the church by the Black preacher. The Black congregation seem to be very enthusiastic about the project. They take the effort to raise enough funds as well as secure land where to build the school. The idea of communal initiative is conveyed by the book's illustrations. There are several pictures showing the Black community either inside or outside the church. The people's facial expressions and gestures indicate their interest and devotion to building the school. Although the construction work is supervised by specialists, the Black community continually participate in the project. One illustration shows a group of African Americans who are listening carefully to Professor James presenting the project of the school. Interestingly, we cannot see the whole body of the educator but only his hands spread over the architectural drawings. It seems that the authority figure is not as important as the whole community striving together to build a brand-new school for their children. The same crowd of people is visible in the picture of the church as well as the ceremony of opening the school.

The primary aim of writing Dear Mr. Rosenwald was to celebrate the Rosenwald Fund which supported lots of Black schools in the American South. As we can learn from the Author's Note, "Rosenwald schools were a sign of progress and a source of pride in African American communities" (Weatherford, 2006, Author's Note, unpaged). However, it is not just about the physical structure of the schools but their educational aspects. As the opening lines of the book say: "You can't judge a school by the building" (Weatherford, 2006, unpaged). For African Americans education has always been political as it gave Black students more opportunities to improve their lives. It was in the Black schools that they learnt about the rights they did not have, and it was the school that inspired them to participate in political struggle. Thus, paradoxically, a segregated Black school, which empowered so many African American students, became a reason to fight for more rights and finally end the segregation system. 


\section{RESISTANCE TO SCHOOL SEGREGATION}

Unlike Weatherford's book, most American children's books published within the last decade convey the belief that racial segregation is wrong and it leads to further divisions in the society. With their rhetoric of political resistance, many of the books encourage their readers to fight any form of racial discrimination in the school. They are often published in response to current political and social problems which concern not only African Americans but also other minority groups living in the U.S. They can be called counter stories because they subvert the white discourse concerning race and ethnicity in educational institutions. Besides, as Janine M. Schall, Julia Lopez-Robertson and Jeanne G. Fain note, "counter stories 'counter' deficit storytelling, are grounded in real-life experiences, and are contextualised in social situations that are also grounded in real life" (Schall, 2019, p. 62). Thus the stories provide an insight into varied experiences which are often missing in the media or scholarly reports.

The following sections of the article will analyse four picture books on the topic of school segregation. Toni Morrison's Remember: A Journey to School Integration (2004) is a collection of press photographs for which the author invents fictional narratives. Most of the words, being the voices of child characters, express their strong desire to make friends with people of the other race, which is presented as the basic reason to end school segregation. Through My Eyes (1999) is an autobiographical story of Ruby Bridges, the first African American child to be sent to the formerly all-white school in New Orleans. Richard Michelson's Busing Brewster (2019), set in Boston of the mid-1970s, focuses on the experience of forced integration and the practice of busing. Duncan Tonatiuh's Separate is never equal (2014) goes back to the pre-Civil Rights period, and unlike the other books, focuses on the problems of Mexican American students who are denied access to the local schools in California. It is based on the historical case of Mendez v. Westminister School District (1947), which ended public school segregation in California, seven years before school segregation became illegal in the whole country due to the Supreme Court decision Brown v. Board of Education (1954). Although the Mendez ruling had a great impact on further proceedings concerning racial problems in American schools, it is not as widely-known as Brown. Using the story of Mexican American children facing the same problem as young African Americans certainly makes the readers realise that school segregation is not only a black problem. All of the stories go along parallel lines, from the stage of rejection and suffering to the moment of racial integration. The accompanying illustrations and photographs complement the verbal text or in some cases tell another story. The aim of this section is to analyse rhetorical devices used by the authors and illustrators to express their protest and resistance to the lack of equal educational opportunities in the U.S. now and in the past, as well as to demonstrate a range of diverse perspectives on the issue.

The struggle of Latino students and their parents, first with the authorities of the school district and then with the state legislation, becomes the central narrative motif of Tonatiuh's book, Separate is never equal. It starts with the Mendez 
family whose children are denied access to the local public school in the District of Westminster, Orange County, California. Instead they are forced to go to the Mexican school. The Mendez parents question the local school authorities as well as invite other coloured families to join in the struggle, which turns into a large-scale protest. First they negotiate with the local school board. Then the case goes to Los Angeles court, which decides that "public education must be open to all children by unified school association irrespective of lineage" (Tonatiuh, 2014, p. 30). However, the school district appeals to the state court in San Francisco. On April 15, 1947, the court confirms the decision of the lower court. Although the book celebrates the efforts of the Mendez family, it also mentions the initiative and support of people from different backgrounds and different parts of the country. Among others, the Mexican American families receive help from the National Association for the Advancement of Coloured People, the Japanese American Citizens League and the American Jewish Congress. Finally, the Mexican children are accepted in Westminster School.

Although the story primarily focuses on Mexican American parents' struggle for school integration, it presents a variety of perspectives on the issue. The Mendez family is determined to send their children to the local public school. They explain their motifs as follows:

It's not fair that our children have to go to an inferior school. It's not only a building that's a problem - the teachers at the school don't care about our children's education. They expect them to drop out by the eighth grade. How will our children succeed and become doctors, lawyers and teachers? (Tonatiuh, 2014, p. 14)

However, their arguments are not strong enough to many other Mexican Americans who refuse to join in their struggle by saying that they do not need any problems from their white employers. As the case reaches the court in Los Angeles, we are confronted with a number of other arguments. The superintendent of one public school admits he sends children to a Mexican school so that they could improve their English as well as learn about proper social behaviour and personal hygiene. He adds that a large percentage of Mexican American students fall behind others in their economic outlook, clothing and the ability to participate in the activities of the school. The accompanying illustrations of Latino children and their parents serve as a response to the above claims. The characters' facial expressions and gestures in close-up reveal their inner suffering. Finally, Mr. Mendez is called to testify in front of the court. He gives his own view on the matter, which seems to be convincing to the judge:

Segregation tends to give an aura of inferiority. In order to have the people of the United States understand one another it is necessary for them to live together, and the public school is one mechanism where all the children of all the people go. (Tonatiuh, 2014, p.29)

The words are followed with a picture of several Mexican Americans reading newspapers with the headline "Ruling gives Mexican children equal rights" as well as celebrating the victory. But this is not the end of the struggle. The last but one illustration, which complements the written text, shows 
people of different skin tones cheerfully heading towards the Golden Gate Bridge in San Francisco, where the trial is to be continued. They seem to be united in their efforts, which are rewarded with the final decision about school desegregation by the Court of Appeals.

The book's illustrations, all featuring the same characters, add a load of emotions to the story. From the picture on the front cover we can judge to what extent school segregation affects relationships between youngsters of different races. The front cover shows white and Latino students, with remarkably different hairstyles and clothes, going in opposite directions towards their own schools. The protagonists' position on the page indicates that they are ignorant of each other while simultaneously being intent on living in their own closed communities. After a dozen illustrations showing the Latino parents' attempt to end school segregation, there is a picture of the same Mexican and white students now playing together in front of the school. But above all integration is celebrated with a symbolic picture of five Latino students placed within a frame marked with the stars and stripes of the U.S. flag, which indicates where they actually belong.

\section{THE STRATEGY OF THE DIFFERENCE}

The physical surroundings of the white schools as well as the educational facilities are one of the reasons why many minority parents wanted their children to participate in the process of integration. Contrasting African American and white schools was a popular strategy of many civil rights activists of the 1950s and 1960s who used a variety of media to demonstrate that segregated schools were not equal. In his article on the legacy of school segregation, Matthew Delmont quotes a Black parent and a civil-rights activist of that period:

The teachers were permanent. We'd see wonderful materials. When we'd go to our schools, we would see overcrowded classrooms, children sitting out in the corridors, and so forth. And so, then we decided that where there were a large number of white students, that's where the care went. That's where the books went. That's where the money went. (Delmont, 2016)

The authors of contemporary picture books use the same strategy in order to explain why minority people were not satisfied with their "own" schools. In Tonatiuh's story, the white school building seems to be a much more appealing place than the Mexican one, which looks like a wooden shed with limited lighting and space. Interestingly, the picture of the white school takes up most of the page. We can see more details: a large parking lot in front of the school, tall trees, a playground as well as spacious and clean halls. The verbal narrative adds more to the significance of the school. All the Latino children who arrive there admire the building in the belief that they can also be there. Similarly, in Busing Brewster, the boys' mother is sure the white school will offer them more opportunities. She tells the boys there is a swimming pool, art and music rooms, a real library full of books, and the roof of the school building does not 
leak. In Morrison's book Remember, the pictures of the classrooms in the Black schools are in contrast with the interior of the white schools having more light, enough desks for all the students as well as a variety of teaching aids. The comments placed under the pictures indicate that it is not just adults who stress the difference but also children who find it hard to study in such neglected places. One illustration depicting a Black child in a segregated school is accompanied with the following words: "In here I am supposed to learn important things. I bet I could be good at learning them if I had a real desk and lots of books and things. I want to. But it's dark in here" (Morrison, 2004, p. 14).

\section{THE CHILD AND THE ADULT PERSPECTIVE}

Except for the details on how minority parents have to fight against racial segregation in order to secure a spot for their children in the previously all-white schools, all the stories reveal African American children's perspectives on racism in the seemingly integrated schools. Some of the kids become aggressive while others experience internal suffering and try to adapt to the new situation just because their parents wish them to do so. The children's attitudes to the new school situation vary depending on their age, emotional bond with their parents or the physical requirements connected with moving to a new school. However, their responses definitely differ from their parents', who never experience what the kids have to go through once they enter a new school.

While the story of Mexican immigrants shows that children, like their parents, are equally determined to join the integrated school, they seem to lose confidence once they are allowed to enter the school. The book's illustrations reveal a variety of emotions that accompany the new students. Unlike white students, who keep their heads up and mouths open as if they wanted to show their superiority and power in their school, Latino characters look as though they are out of place. Some of them are usually far from the lockers where all the students meet in the morning. Their crying faces indicate the problem of bullying and contempt they suffer due to the lack of tolerance from the white part of the school community. The younger students seem to be confused about the situation. For instance, one Mexican American girl asks herself: "Am I different?" while being rejected by her white peers. However, there are some Latino children who perfectly understand the problem and try to accompany their parents in their struggle for equal school opportunities. One fourteen-year-old girl was even called to speak in the court. The fact that her English was perfect became a strong argument for integrating California schools.

In most African American picture books, parents are enthusiastic about the prospect of sending their children to an integrated school, even if it means busing the kids across the town. They believe it is a form of social advancement and provides opportunities that Black children would not otherwise have. For instance, in Michelson's book, once Brewster's mother gets a letter from the formerly white school that her boys have been admitted, she proudly informs 
her sons of the new chance. Trying to conform Brewster, she says the school will totally change his life and adds proudly: "Maybe you'll be president someday, Brewster" (Michelson, 2014, unpaged). The boys, on the other hand, are not that happy. The older one, Bryan, steps back once his mum wants to hug him upon getting the news. Then all through the night he reveals his emotions by punching his pillow and nagging about having to get up early and sitting on a bus for an hour. He is sure the school will not be good for him because, as he says, "Central is a white school! Ain't no Negroes at Central" (Michelson, 2014, unpaged). The younger boy, Brewster, now knowing much about the new school, becomes scared, which is marked with the illustration showing the boy hiding under his blanket. The first day at school is not nice either. Once the Black kids approach the school, they see white people lined up on both sides of the street protesting against school integration. The situation gets much worse when a rock shatters the school bus window. Then white kids greet the boys with insults, which leads to a confrontation and a day's long detention in the library. Once the boys return home, again they can hear their mum getting excited about the new school. The younger boy, not wanting to worry her, pretends the first day was fine: "I spent the whole day in the library. Someday I'm going to be president" (Michelson, 2014, unpaged). For Black children the process of integration means mental and physical pain. The story indicates that for parents it is a totally different experience. They can be the agents of change by helping their child get a place in a new school, but they are never inside the place, like their kids experiencing the effects of integration in person.

In all of the books, child characters sent to the new schools know there is no way out. The children seem to understand they are part of the political process which is supposed to improve the lives of future generations. The words of one of the students of colour placed in Morrison's book suggest that they realise they have to be there no matter the pain:

Walking through a crowd of people who hate what we are-not what we do-can make us hate them back for what they are and what they do. A lot of courage and determination are needed not to. We try. . .

but sometimes...

Soldiers with rifles stop me. (...)

I eat alone. No one looks at me. (Morrison, 2014, p. 35-40)

Another child says:

I can't see anything but the dark inside the door. My father is strong and smart. He holds my hand in his big fist. When he leaves me here I'll have to be strong too. I can do it. I know I can, even though all I can see in front of me now is the dark. (Morrison, 2004, p. 48)

Having supportive parents, Black children are wondering how it is possible that white adults resort to such measures as public protest in front of the school: "They are trying to scare me. I guess they don't have any children of their own. But didn't grown-ups used to be little kids who knew how it felt to be scared?" (Morrison, 2004, p. 45) 


\section{INTEGRATION AS A PROCESS}

In all of the picture books, school integration is presented as a long-lasting process marked with the stage of rejection, the transition period of getting used to the new place, and the real integration which takes place not only on the institutional level but also interpersonally. All of the characters go through the stage of rejection once they enter the white school or even prior to that. They experience lack of support from their white peers as well as school authorities.

The Mexican children in School is Never Equal get rejected several times until they are allowed to enter the integrated school. What is going on in the family as well as the selected Latino communities is well included in the written narrative, which can be analysed as a script of negotiations between both sides of the conflict. Added to this, the book's illustrations reveal a variety of emotions accompanying the young characters during their struggle, from the feeling of shame caused by their "otherness" to the humiliation of having to spend their school time in appalling conditions and lunch breaks near the cow pasture. They are frequently reminded that they are strangers to this land, and, as Janine Shall concludes, need to be treated as "controlled bodies" (Shall, 2019, p. 69). However, their struggle would not have been possible had it not been for family solidarity and the extended immigrant community. Having experienced the same problem of rejection, several Latino families get together and finally succeed. The illustrations showing Latino immigrants from different California districts collaborating in their efforts beam with positive feelings. There is more optimism and determination to continue the struggle, which is marked with the characters' facial expression as well as their central position on the page. From there on, they keep their heads up and become more confident in what they are doing.

The autobiographical story of Bridges, Through My Eyes, reveals the child's perspective on the process of integration. Having been sent to the white school, a seven-year-old girl initially finds it hard to understand the whole situation. In her case, rejection is a wider term as her appearance in the school had led to larger protests against school integration. The book's illustrations, which are real press photographs from the early 1960s, extend the contents of the simple story. Ruby is rejected not only by her white peers but also by their parents as well as the whole white local community. Within the first few weeks she has to be escorted by the police on her way to school as she is followed by angry crowds wanting her to go back to the all-black school. The photographs of desegregating the school take up almost half of the book, which emphasises the length of the period and the child's suffering. Finally, there is the picture of Ruby playing with a group of white kids whose parents agreed to send them back to school, which is an expression of the interpersonal integration.

The moment of school integration is the main narrative element in most of the books. While some authors celebrate the fact with entirely positive pictures of all children becoming friends, others still reflect on the initial suffering of the children of colour. There is a seminal photograph in Morrison's book, 
which shows two girls of different races staring at each other in the integrated classroom. The words placed on the next page reveal what is going on in the mind of the Black child: "I think she likes me, but how can I tell? What will I do if she hates me?" (Morrison, 2004, p. 23). Other photographs show empty classrooms in the schools which opened their doors to children of colour. There are just a few Black kids sitting at their desks, which is explained by the following words: "When they let us in the school, none of the white students came. Their parents made them stay home" (Morrison, 2004, p. 31). The pictures portraying Black kids standing in front of the school are especially moving. One of the double-spreads shows a picture of several Black girls looking straight into the eyes of the reader accompanied with the following text: "No, no, they said. You can't come in here. Get away from the door. This school is for white children. Only them" (Morrison, 2004, p. 32).

Finally, there is the stage of real integration. Black and white students or Latinos and whites become friends. Morrison celebrates this fact with a close-up photograph of two girls sitting next to each other in a school canteen. Underneath the illustration the following words appear: "I see in her face just a girl. She sees in my face another girl. Maybe not friends, but simply girls together" (Morrison, 2004, p. 42). Although the book is written from the perspective of a Black girl, one could easily wonder whether these are the thoughts of the African American or the white girl. The story of Mexican American children ends on a positive note as well. The book's main character, Sylvia, enters the local school with the belief that her parents fought for this opportunity. Such a belief made the girl ignore any negative remarks from other children, and instead hold her head high. The final illustration of the book shows white and Latino children playing together in the school playground. The girls are looking in the same direction while the boys are staring at each other with the same friendly expression on their faces (Tonatiuh, 2014, pp. 34-35). Unlike in the previous pictures, there are no feelings of inferiority or superiority on either side.

\section{FINAL REMARKS}

All of the picture books show that the way to integration is hard but not impossible. This message is relevant today as schools in America are as segregated by race as they were in the 1960s. As Keath Meatto writes for The New York Times, "More than half of the nation's schoolchildren are in racially concentrated districts, where over 75 percent of students are either white or nonwhite" (Meatto, 2019). In addition, a growing number of school districts are often segregated by income, which leads to further educational gaps between white students and students of colour, as well as rich and poor students.

Despite the crisis in American schools, segregation and people's attempts to end it are regarded as historical facts. Students might be aware of the historical desegregation rulings but they are never taught that the issue concerns them personally. As Meatto notes, "segregation as a current reality is largely 
absent from the curriculum" (Meatto, 2019). Hardly any American students are instructed about the drawbacks of segregation or the benefits of studying in a multicultural setting. Thus, for many students of colour, children's picture books may be the only printed resources which, besides informing them of the historical school segregation, make them realise that it is also their problem.

Many contemporary authors of children's literature believe the civil rights movement is a never-ending struggle on the part of Black Americans as well as other minorities. Jacquelyn Dowd Hall uses the concept of "long civil rights movement" to explain that it is a long complicated narrative which has not been completed yet. In the same way, a growing number of Black and Latino writers insist that the struggle is continuing because race is still a crucial issue in the cultural and political life of the United States. Thus their stories are supposed to affect the readers' understanding of the past as well as the present situation. Morrison imagines the black struggle is not finished and tries to convince her readers they are part of this history. In the preface to her children's book, Remember, she addresses them in the following way: "This book is about you. Even though the main event in the story took place many years ago, what happened before it and after it is now part of all our lives" (Morrison, 2004, p. 3). Similarly, Michelson expresses how his story is relevant today: "In 2019, as Busing Brewster is being republished, our country is again grappling with an upsurge in racially motivated bullying in classrooms and hallways, mirroring an increasing number of hate crimes in society at large. We must do better. Education and empathy are key. We must support our children by supporting parents and funding schools" (Michelson, 2019, unpaged). Finally, Tonatiuh believes his story of the Mendez family will inspire contemporary immigrant children: "I also hope they will see themselves reflected in Sylvia's story and realise that their voices are valuable and that they too can make meaning contributions to the country" (Tonatiuh, 2014, p. 36).

By demonstrating a diverse range of perspectives on race issues in American schools, children's authors stress the fact that school integration is a community experience. There are usually two sides of the conflict, white Americans and the Black or Latino minority, who need to reach a consensus. In addition, within these two groups, there are children and adults who also hold different views on integrating races in one school. Reading children's picture books on school segregation may help all sides to the conflict. White readers, when confronted with the counternarratives, may realise that integration is possible without them losing the existing opportunities. Minority readers will definitely feel empowered to continue their efforts in the way to school integration. Parents of colour have a chance to recognise the emotional impact of forced integration on their kids and get an instruction on how to lead their offspring safely through the process. Finally, white parents can understand that relationships with the other race will help their children better understand their place in a multicultural society. The four stories discussed in the article present a counternarrative to the white discourse on school integration, which is predicated on the belief that mixing races in schools leads to more intole- 
rance and crime. The books provide access to the experience of students of colour who have been marginalised in the U.S. schools and place the stories front-and- centre. Although the books do not spare the readers with the episodes of suffering, they prove that the collaboration of races can change the status quo in American society.

\section{REFERENCES}

[1] Bridges, R. (1999). Through My Eyes. New York: Scholastic Press.

[2] Delmont, M. (2016). The Lasting Legacy of the Busing Crisis. The Atlantic. Retrieved from https://www.theatlantic.com/politics/archive/2016/03/the-boston-busing-crisis -was-never-intended-to-work/474264/.

[3] Dowd Hall, J. (2005). The Long Civil Rights Movement and the Political Uses of the Past. The Journal of American History, Vol. 91, No. 4: 1233-1263.

[4] Kohli, S. (2014). Modern-Day Segregation in Public Schools. The Atlantic. Retrieved from https://www.theatlantic.com/education/archive/2014/11/modern-day-segregation -in-public-schools/382846/.

[5] Martin, M. H. (2004). Brown Gold: Milestones of African-American Children's Picture Books, 18452002. New York and London: Routledge.

[6] Meatto, K. (2019). Still Separate, Still Unequal: Teaching about School Segregation and Educational Inequality. The New York Times. Retrieved from https://www.nytimes. com/2019/05/02/learning/lesson-plans/still-separate-still-unequal-teaching-about-schoolsegregation-and-educational-inequality.html.

[7] Michelson, R. (2019). Busing Brewster. Jeffrey, NH: David R. Godine, Publisher.

[8] Morrison, T. (2004). Remember: The Journey to School Integration. Boston: Houghton Mifflin Company.

[9] Reardon, S. F., \& Owens, A. (2014). 60 Years After Brown: Trends and Consequences of School Segregation. The Annual Review of Sociology, 40:199-218.

[10] Schall, J. M., Lopez-Robertson, J., \& Fain, J. G. (2019). Examining the Visual in Latinix Immigrant Journey Picturebooks. In H. Johnson, J. Mathis and K. G. Short (eds.), Critical Content Analysis of Visual Images in Books for Young People: Reading Images. New York and London: Routledge.

[11] Stancil, W. (2018). School segregation is not a myth. The Atlantic. Retrieved from https:/ / www. theatlantic.com/education/archive/2018/03/school-segregation-is-not-a-myth/555614/.

[12] Tonatiuh, D. (2014). Separate is never equal: Sylvia Mendez and Her Family's Fight for Desegregation. New York: Abram Books for Young Readers.

[13] Weatherford, C. B. (2006). Dear Mr. Rosenwald. New York; Routledge. 